\title{
EGF A61G Allele
}

National Cancer Institute

\section{Source}

National Cancer Institute. EGFA61G Allele. NCI Thesaurus. Code C78136.

Human EGF A61G allele is located in the vicinity of 4 q25 and is approximately $99 \mathrm{~kb}$ in length. The A61G allele is a polymorphism in the promoter region of the EGF gene where an adenosine residue is replaced by a guanosine at position 61 in the genomic DNA, which encodes pro-epidermal growth factor precursor protein. This allele may be associated with aberrant expression of the protein and decreased incidence of cirrhosis, hepatocellular carcinoma, malignant melanoma and gastric cancer. 